Ausra Vasiliauskaite (sr. Gabriele OSB)

ORCID: https://orcid.org/0000-0003-0400-3527

iDs 10324141

Vytautas Magnus University, Lithuania

\title{
An Overview of the Documents of the Archive of Kaunas Benedictine Convent
}

\begin{abstract}
In 2024, Kaunas Benedictine Convent will celebrate its $400^{\text {th }}$ anniversary. Throughout this period, the convent's existence has not been interrupted. During the Soviet period, from 1948 to 1988, the convent still operated in secret. However, the archives of the convent began to be organized anew at the beginning of the $21^{\text {st }}$ century revealing important documentation not only for the convent, but also for monastic research. It is for this reason that this article aims to present the documents of Kaunas Benedictine Convent's archive.
\end{abstract}

\section{Keywords}

Archive of Kaunas Benedictine Convent, archival funds of Kaunas Benedictine Convent

\section{Introduction}

The Kaunas Benedictine Convent has been operating in Lithuania for almost 400 years. In the $16^{\text {th }}-17^{\text {th }}$ centuries, in the Grand Duchy of Lithuania, approximately 20 women's convents had been founded (Bernardine, Benedictine, Bridgettine, 
Dominican, Discalced Carmelite, St. Catherine, and Visitandine). However, only three monasteries have remained to these days: the Benedictine convents in Kaunas and Vilnius and St. Catherine's Convent in Krakès. Since the foundation of the convent in 1624, the Kaunas Benedictine sisters collected and stored documents as evidenced by a rather abundant archive including material from the first half of the $17^{\text {th }}$ century to present days. The purpose of this research is to present the composition of the archives and document types at the Kaunas Benedictine Convent, to describe the peculiarities of how the Kaunas Benedictines' archive formed, the changes that have taken place over the centuries, and to highlight the importance of the archive for monastic research.

In 2012-2014, a group of scientists of Vytautas Magnus University (Sr. Gabrielè Aušra Vasiliauskaitė OSB, Vaida Kamuntavičienė, Aušra Vasiliauskienė, and Kęstutis Žemaitis) investigated the history, art and theology of Kaunas Benedictine Convent. ${ }^{1}$ As a result, in 2015, part of the document catalogue of the Benedictines' archive (from the $15^{\text {th }}$ to the beginning of the $20^{\text {th }}$ century) was published in Lithuanian, in Kaunas History Chronicle (Kauno istorijos metraštis). ${ }^{2}$ However, the document catalogue of the $20^{\text {th }}$ century has not been published so far. Therefore, it is meaningful to continue the initiated research and to present a more comprehensive description of the Kaunas Benedictines' archive stored at Kaunas Benedictine Convent (address: Benediktinių St. 10, Kaunas, Lithuania).

It should be noted that documents related to the history of Kaunas Benedictines can be found in various Lithuanian and foreign archives (for example, in the Princes Czartoryski Library in Krakow (Biblioteka Książąt Czartoryskich)). Especially important are the archives of Vilnius, Samogitian and Kaunas Dioceses (until 1849, Kaunas belonged to the Diocese of Vilnius, then to the Diocese of Samogitia, and from 1926 to the present day to the Archdiocese of Kaunas). Part of the old documents of these dioceses, the Samogitian land court and other documentation related to the legal and economic situation

${ }^{1}$ Research results have been published in two studies: V. Kamuntavičienè, Kauno benediktiniu vienuolyno tyrimai, t. 1. Kauno benediktiniu vienuolyno istorija XVII-XX a. pradžioje, Kaunas 2016, VDU, Versus Aureus; A. Vasiliauskienè, Kauno benediktiniu vienuolyno tyrimai, t. 2. Kauno benediktiniu vienuolyno menine savastis, Kaunas 2016, VDU, Versus Aureus. At present, research of the $20^{\text {th }}$ century documenation is being conducted.

${ }^{2}$ V. Kamuntavičienè, A. Vasiliauskaitè (Sr. Gabrielè OSB), A. Vasiliauskienė, K. Žemaitis, Kauno benediktiniu archyvo XV-XX a. pradžios dokumentų katalogas, "Kauno istorijos metraštis" 15 (2015), pp. 287-295. 
of Benedictine sisters are stored in the Lithuanian State Historical Archives (documentation of Samogitian Diocese, the Old Acts, etc.), the Wroblewski Library of the Lithuanian Academy of Sciences (documentation of Vilnius chapter, Kaunas Benedictine sisters' funds, etc.), the Manuscript Department of Vilnius University Library (Samogitian land court fund, etc.), and other establishments. The most recent documents of the $2 \mathrm{O}^{\text {th }}$ century, especially related to the persecution of sisters during the Soviet Period, are stored in the Lithuanian Central State Archives or the Lithuanian Special Archives. However, the Kaunas Benedictines' archive collected by Benedictine sisters is especially important for the formation of a more complete picture of the convent's history.

\section{The Formation of Kaunas Benedictines' Archive}

The archive of Kaunas Benedictine Convent began to form in the $17^{\text {th }}$ century when the first Benedictine sisters came to Kaunas from Nesvizh and settled in Rekutis manor, in 1622, at the invitation of the marshal of Kaunas district (pavietas) and chevalier of the Order of Jerusalem, Andrzey Skorulski. ${ }^{3}$ The sisters brought the first documents and books with them. These personal documents were supplemented by land ownership documents from the beginning of the $16^{\text {th }}$ century: on November $28^{\text {th }}, 1624$, Andrzey Skorulski issued a foundational document donating the Benedictine sisters land (Raginè (Roginie)) near Kaunas and Sudvariškès (Sudwoiszki). In 1621, King of Poland and Grand Duke of Lithuania Sigismund Vaza donated the Benedictine sisters St. Nicholas Church $^{4}$ near Kaunas, whereas Vilnius Bishop Eustachy Wołłowicz approved this order in $1627 . .^{5}$ In this way, Benedictines acquired the church documentation dating to the end of the $15^{\text {th }}$ century, as the Church of St Nicholas was built in the $15^{\text {th }}$ century.

${ }^{3}$ Vidra (Rekučio) manor inventory, Kaunas, 162202 28, Lietuvos mokslu akademijos Vrubevskiu bibliotekos Rankraščiu skyrius (MAB), f. 38-3, 1. 20-21. Kristupas Kulvinskis made and inventory of the manor before transferring it to Andrzey Skorulski. Extract from Kaunas acts 162212 02, Lietuvos nacionalinis muziejus (LNM), R 11660-5. This act mentions the convent of Benedictine sisters near the borders of Kaunas town.

${ }^{4}$ Privilege of Sigismundus Vaza, Warsaw, 162109 27, Kauno arkivyskupijos kurijos archyvas (KAKA), b. 14, 1. 230; Biblioteka Czartoryskich, BCz. 1775, 1. 963.

${ }^{5}$ E. Valavičius's document, Vilnius, 162709 15, Kauno benediktinių archyvas (KBA), 7-2-20. 
The Kaunas Benedictines' archive gradually grew by adding new land ownership documentation, daily economic documents, various contracts with peasants of the land, purchase and sale acts, household and church inventories, correspondence documents, court cases, writings of bishops or other hierarchs, letters of governmental institutions, etc. Kaunas Benedictines' holdings survived some disasters such as fires. For example, a document written on September 20, 1653, testifies that 20 houses were completely burned down in Raginè suburb owned by the convent; ${ }^{6}$ during the Russian occupation in the second half of the $17^{\text {th }}$ century, a part of the archives of the convent taken to Paštuva was destroyed by the fire.

From time to time archival registers were compiled. The first remaining registers date back to the second decade of the $17^{\text {th }}$ century; they are signed by the first abbess of the convent Ona Eufemia Skorulska, the daughter of the founder of the convent.' Archival documents were very important legal acts used to litigate on land holdings, peasant dependence, and other affairs. Therefore, they are carefully registered and stored. The register of the holding documents written in $1819-1820$ is a thick book consisting of 201 pages. The documents were divided into 4 parts according to the main land holdings (Raginè, Sudvariškès, Petrašiūnai (Pietraszuny), Paštuva (Pocztowo)). These four parts were organized into packs (fascykuły): the holding documents of Raginè and Sudvariškès consisted of 8 packs, Petrašiūnai -12 , and Paštuva -6 packs. ${ }^{8}$

Documents related to the religious life of the sisters can also be found in the Kaunas Benedictines' archive. For example, the acts of Benedictine vows of the $19^{\text {th }}-20^{\text {th }}$ centuries, documentation of church and convent visitations and inventories. In 1897, Kražiai Benedictine Convent was closed, and sisters moved to live in Kaunas. In this way, the documentation of Kražiai Benedictines appeared in the Kaunas Benedictines' archive. In 1934, the convent' archive was described in the following way: "two chests of old documents in Latin, Belorussian, Russian, and Polish languages." ${ }^{9}$ As is seen, the archives were stored in large chests which evidences that the nuns, since their first settlement in Kaunas, have

\footnotetext{
${ }^{6}$ V. Kamuntavičiene, Kauno benediktinių vienuolyno tyrimai, t. 1, ibid, p. 106.

${ }^{7}$ Document register compiled by K. Kulvinskis, given to A. Skorulskis, signed by O. E. Skorulskyte, [approx. 1625], $M A B$, f. 38-3, 1. 12-13.

${ }^{8}$ The register of economic documents of the Kaunas Benedictine Convent, 1919-1920, Lietuvos valstybes istorijos archyvas (LVIA), f. 696-2-967.

${ }^{9}$ Visitation of Kaunas Benedictine Convent, 1934, KBA, 21-1-2, 1. 15.
} 
appreciated and stored the archive as the greatest and most precious treasure and as a heritage and inheritance for future generations.

At the end of the Second World War, Lithuania was occupied by Soviet Russia. According to the order of the occupational authorities, in 1948-1949, all Lithuanian monasteries were liquidated in a year and a half. Kaunas Benedictine Convent (with 12 sisters living in the convent at that time) was also closed. Kaunas women's monasteries were liquidated practically in one day, on August 25, $1948 .^{10}$ According to the memories of Kaunas Benedictines, they were ordered to leave within 48 hours. The sick and the old sheltered in the corridor connecting the convent and the church. The corridor was referred to as furtyte in Lithuanian (from the Polish word furta). Along with the convent, St. Nicholas Church was also closed and the adoration of the Blessed Sacrament disrupted. ${ }^{11}$ St. Nicholas Church was turned into a book storehouse. In 1948-1963, it belonged to the national library, ${ }^{12}$ whereas in $1963-1990$, it was used as a storage of the Kaunas Public Library. The installed book racks destroyed the whole interior of the church.

When Kaunas Benedictine Convent was closed, the entire convent archive had to be handed over to the state for storage, however, the Benedictine sisters did not agree with it. They sought to preserve the most important monastic documents as, for example, the material related to the founder Andrzey Skorulski. The Benedictine sisters have also preserved some of the $19^{\text {th }}$ century economic documents (perhaps inadvertently not confiscated by government representatives) and certain interwar period cases as having practical significance at that time. Some documents were hidden in the basement of the church, others were taken away with them or hidden in furtyte, where the sick were lying, and others had to be given to the soviets. In general, a larger part of the documents was confiscated and taken to different archival institutions of Lithuania.

The largest part of the old Benedictine archive was placed in the Manuscript Department of the Wroblewski Library of the Lithuanian Academy

${ }^{10}$ R. Laukaityte, Lietuvos vienuolijos. XX a. istorijos bruožai, Vilnius 1997, Lietuvos istorijos institutas, pp. 136-139.

${ }^{11}$ Verification that St. Nicholas Church in Kaunas is really closed: statistical data on Kaunas Catholic Archdiocese's churches and cult servants, December 31, 1950, Lietuvos centrinis valstybès archyvas (LCVA), f. R-181, ap. 1, b. 55, 1. 76.

A. Jankevičienè, Dar apie šv. Mikalojaus bažnyčia, "Kauno tiesa" 88 (1990), p. 5. 
of Sciences. In 1953, the Benedictines' fund (No 38) containing 144 cases was formed. Another part of the archive was taken to the National Museum of Lithuania where it stayed in boxes during the whole Soviet Period. Only at the end of the $20^{\text {th }}$ century, Kaunas Benedictine Convent's fund with over 100 cases from $16^{\text {th }}$ to the beginning of the $20^{\text {th }}$ century was formed. Some documents appeared in the Curia archives of the Kaunas Archdiocese (c. 82, 89 , etc.), where they were stored and used by Curia's archivist, priest Petras Veblaitis.

On March 11, 1990, after the restoration of an independent state of Lithuania and liberation from the soviet occupation, Kaunas Benedictines were able to return home. Already in 1989, a Committee on the Restoration of the Church was formed. It was chaired by Mons. Assoc. Prof. Vytautas Sidaras who took care of the restoration of St. Nicholas Church. On March 25, 1992, the Benedictine church was ordained, devoting it again to the adoration of the Blessed Sacrament. Thus, the Benedictine sisters were able to come back home, evict the residents of the convent (turned into a builders' dormitory) as well as return to the legacy of the Blessed Archbishop Teofilius Matulionis - the adoration of the Blessed Sacrament.

After the restoration of Kaunas Benedictine Convent, the archive was also recreated. Unfortunately, the document losses during the Soviet Period were significant. For example, the original foundation document of Andrzey Skorulski written in 1624 did not survive. From the remaining documents, the sisters began to form monastic archive and established 27 funds.

It is important to emphasize that the funds are constantly being supplemented with new documents, photographs, things, etc., which are left by the deceased sisters. Therefore, the register of the archive is also constantly changing. Due to the personal information about the sisters, the archive is kept private and can only be used with the permission of Reverend Mother.

\section{An Overview of the Archival Funds of Kaunas Benedictine Convent}

The Benedictine archive consists of 26 document funds. The old books are stored in the $27^{\text {th }}$ fund and periodicals in the $28^{\text {th }}$ fund. In this section, we will overview the funds of the archive, present their contents and the most important documents stored. 
In the $1^{\text {st }}$ fund of Kaunas Benedictine Convent, all received and sent documentations of the convent (over 2,400 pages) from 1907 to 2003 are kept. The material includes general sent and received writings from various institutions related to the admission of sisters into the convent, novice vows' ceremonies, the election of Reverend Mothers, renovation and interior restauration works of St. Nicholas Church, the issues of the convent reform of the third decade of the $2 \mathrm{O}^{\text {th }}$ century, and the closing of the convent in 1948. Correspondence with the Curias of Samogitian and Kaunas Dioceses, the Holy See, and the Apostolic Visitor Antonino Zecchini (for example, writings from Rome confirming the authenticity of the relics, letters on remissions, etc.) is also stored in the $1^{\text {st }}$ fund. Of particular importance is a group of letters on the closing of Regina Pacis Convent of Benedictine Sisters, which operated in Bedford, in the United States from 1948 to 1997 (Kaunas Benedictines who escaped from the soviet occupation found shelter in this convent). Various documentation, sermons, or accounts related to the convent left by the visitator Father Samuel Russel, lists and documents of sisters who lived in Bedford's Convent (Sr. Agnes Cyzaite, Sr. Casimir Petkeviciute, Sr. Alfonsa Eidimtas) are also kept here.

The $2^{\text {nd }}$ fund contains a large number of photographs. At present, $19^{\text {th }}-20^{\text {th }}$ century photographs have been registered and are being scanned (currently, about 1,00o photos have been processed). Most of them (860 photos) depict Benedictine sisters of the $20^{\text {th }}$ century, their family and relatives, homesteads and animals. Other 182 photos depict the church and convent, their maintenance, even the repair of the convent fence in 2000. 8 exceptional photos show Easter caskets of Kaunas Benedictines' church (1993-2000), and 3 photos show Christmas Crib (1981-1998). The archives contain 66 photographs of the stained-glass windows of the Kaunas Benedictines' church before the restauration taken about 1990. Over 2,000 photos will be processed in the future.

The $3^{\text {rd }}$ and $4^{\text {th }}$ funds contain the personal sisters' manuscripts, which help to form a general image of the $20^{\text {th }}$ century community i.e., what were the sisters as personalities, what they were interested in, what they read, etc. The notes and thoughts of the sisters of the $20^{\text {th }}$ century are stored in the $3^{\text {rd }}$ fund, whereas their lecture materials, manuscripts from different areas of studies are in the $4^{\text {th }}$ fund. These funds are not yet thoroughly investigated, new material is added each year. However, only nuns can get access to these documents.

The $5^{\text {th }}$ fund is devoted to obituaries and memorialization of the deceased sisters. In the $20^{\text {th }}$ century, obituaries (152 pages) were largely written by Sr. 
Boleslova Aleksandra Girevičaitė (Girewiczówna), Sr. Liudgarda Elena Julija Miniataite (Miniatówna), and Sr. Leonija Birute Širvinskaitė. There is also memorializing documentation about Sr. Leonija Birute Širvinskaitè, Sr. Benjamina Halina Michelevičiūtè, and Sr. Benedikta Justina Dobkevičiūtè, various funeral photos, death certificates, etc., from the first decade of the $20^{\text {th }}$ century (79 pages in total).

In the $6^{\text {th }}$ fund, the property documents, the church and convent household inventories and other letters related to the convent's economic affairs, and the inventory of the Kražiai Church and convent, written in 1889, are kept. Also, the $6^{\text {th }}$ fund stores lease documents of plots and houses under the jurisdiction of Benedictines from 1851 to the fourth decade of the $20^{\text {th }}$ century; books on income and expenditure (the oldest one dating to 1900); household books including cadastre and registry files since 1948, tenants' book kept since 1939, and house book kept since 1958. Sales agreement of Paštuva - Kvesai land (1924) and other related documents are also available here.

A very important group of documents in this fund relate to Kačiūniškès (Kaczeniszki) manor, built by the nuns in the beginning of the $20^{\text {th }}$ century. The manor had a large farm and an exclusive orangery. The fund includes the inventory or Kačiūniškès of 1934 and 1940, farm description of 1938, various receipts (1928-1939), notifications, policies and documents related to restoration of ownership rights to Kačiūniškès (1990-2010). Finally, a research paper on "The Growing of Cabbages in the Kačioniškių Farm of the Benedictine Convent" (Gūžinių kopūstu auginimas s. benediktiniu vienuolyno ūky, Kačionišky) written in1937, by Sr. Serafina Zuzana Lapaite is available in the fund. In total, the files consist of more than 2,180 pages.

The $7^{\text {th }}$ fund contains the oldest documents of the church: the first mentioning of this stone building in the Roman Cardinals' writing of 1493 to the priest Stanislovas of the St. Nicholas Church. This document allowed to organize the feast during the days of St. Nicolas, St. Margaret, St. Magdalen, St. Bartholomew and Church consecration. The letter is not an original, but rather a Polish transcript made in the $18^{\text {th }}$ century which has a mistake in the date (1495 instead of 1493). ${ }^{13}$ The $16^{\text {th }}$ century documents include: the king Stephen Báthory's privilege to the Kaunas standard-bearer Jonas Vidra (written in 1577) allowing

${ }^{13}$ The Roman Cardinals' writing to the priest Stanislovas of the St. Nicholas Church, Rome, 149512 04, KBA, 7-1-1. 
to build an inn in Kaunas suburb; ${ }^{14}$ the testament of Motiejus Marcinovičius (1583). ${ }^{15}$ The $17^{\text {th }}$ century documents relate to the foundation of Kaunas Benedictine convent: the documents of the first abbess Sr. Eufemija Ona Skorulskyte and her father, the founder of the convent; Sigismund Vasa's writing (1621) on the establishment of the Benedictine Convent in Kaunas and the donation of the abandoned St. Nicholas Church $;^{16}$ the testament of Andrzey Skorulski (1623) $;^{17}$ the Lithuanian translation of the foundation document of Andrzey Skorulski $(1624) ;{ }^{18}$ an extract from the land court book of Kaunas County (1625) on the approval of Skorulski's foundation for Benedictines; ${ }^{19}$ Eufemija Ona Skorulskytès writing on the succession of St. Nicholas Church (approximately 1637); $;^{20}$ the writing of the Vilnius Bishop Eustachijus Valavičius on the donation of St. Nicholas Church (1627). ${ }^{21}$ This fund also holds documentation relating to other Benedictine possessions: summons to court, litigations, wills, and holding inventories of the $17^{\text {th }}$ century. The $18^{\text {th }}$ century documents contain the following original writings: the letter of Gegužinës Parson, Paweł Franciszek Tołoczko, approving the Benedictine Chaplain (1710); the writings of Vilnius bishops as, for example, the letter from Jesuit Laurentius Ricci from Rome on the recognition of relics of St. Nicholas Church (1767); the bull of Pope Benedict XIV allowing the nuns to establish the Confraternity of the Most Sacred Heart of Jesus at St. Nicholas Church (1756); ${ }^{22}$ the document of Veronika Modesta Zabitovska (Weronika Modesta Zabitowska) eternal vows (1780) given to the abbess of Kražiai Convent

${ }^{14}$ The king Stephen Báthory's privilege to the Kaunas standard-bearer Jonas Vidra, 1577 $1204, K B A, 7-2-23$.

${ }^{15}$ Testament verification of Motiejus Marcinowicz,1583, KBA, 7-2-3.

${ }^{16}$ Sigismund Vasa's writing, 162109 27, KBA, 7-2-25.

${ }^{17}$ The testament of Andrzey Skorulski, 162303 10; the writing of the abbess of Kaunas Benedictines, Eufemija Ona Skorulskyte, to peasants of Sudvoiškès, 164007 08, KBA, 7-2-21.

${ }^{18}$ The Lithuanian translation of the foundation document of Andrzey Skorulski, 1624 $1128, K B A, 7-2-24$ (typescipt).

${ }^{19}$ An extract from the land court book of Kaunas County (1625) on the approval of Skorulski's foundation for Benedictines, 162501 16, KBA, 7-2-17.

${ }^{20}$ Eufemija Ona Skorulskytës writing on the succession of St. Nicholas church, [approx.1637], $K B A, 7-2-2$.

${ }^{21}$ The writing of the Vilnius Bishop Eustachijus Valavičius on the donation of St. Nicholas Church, 162709 15, KBA, 7-2-20.

${ }^{22}$ The bull of Pope Benedict XIV allowing the nuns to establish the Confraternity of the Most Sacred Heart of Jesus at St. Nicholas Church, 175601 10, KBA, 7-1-5. 
Antonija Skolastika Mackevičiūtė (Antonia Skolastyka Mackiewiczówna). Some of the more exceptional documents of the $19^{\text {th }}$ - beginning of the $20^{\text {th }}$ centuries are as follows: the writing of Raimondas Stasiulewicz from Paparčiai Dominican Monastery (1845) which allows the establishment of the Confraternity of the Rosary; ${ }^{23}$ the letter of Bishop Motiejus Valančius (Maciej Wołonczewski) (1861) resending (in 1862) the letter from the Prior Provincial of the Dominican Order Simonas Gavarskis (Szymon Gawarski). ${ }^{24}$ The largest document collection of the $7^{\text {th }}$ fund comes from the last decade of the $20^{\text {th }}$ century when St. Nicholas Church was returned to Benedictines. The documents relate to the return of the church and the sacral art values which belonged to St. Nicholas Church, the research of its state, church drawings, and its restoration projects.

The $8^{\text {th }}$ fund contains documentation from the beginning of the $2 \mathrm{O}^{\text {th }}$ to the $21^{\text {st }}$ centuries such as accounts, invoices, monastery accounting, receipts, checks, taxes, and work estimates. There are more than 500 pages in these files.

The $9^{\text {th }}$ fund includes copies of documents related to the history of Kaunas Benedictines from other archives: Kaunas Regional Archives, Archives of the Curia of Kaunas Archdiocese, Lithuanian State Historical Archives, Lithuanian Central State Archives, Lithuanian Special Archives, Manuscript Department of Vilnius University Library, National Museum of Lithuania, the Manuscript Department of the Wroblewski Library of the Lithuanian Academy of Sciences, M. K. Čiurlionis National Museum of Art, the Microfilm Department of the National Library of Poland in Warsaw (which stores the microfilms of the library documents of the Princes Czartoryski Museum in Krakow), the Central Archives of Historical Records in Warsaw, and the National Historical Archives of Belarus. The number of these documents exceed 1,000 pages.

The $10^{\text {th }}$ fund includes letters, greetings, leaflets, and postcards that Benedictines received from Lithuania and other countries (from 1918 to the beginning of the $21^{\text {st }}$ century). Particularly important are letters to sisters received from Siberia, dating $1944-1998 .^{25}$ These files are made up of more than 1,380 pages.

The $11^{\text {th }}$ fund contains audio recordings of the convent. In the $12^{\text {th }}$ fund, works written by the nuns are kept: BA and MA theses, licentiates, course papers, etc.

${ }^{23}$ The writing of Raimondas Stasiulewicz from Paparčiai Dominican monastery allowing to establish the Confraternity of the Rosary, 184510 01, KBA, 7-1-3.

${ }^{24}$ The letter of Bishop Motiejus Valančius, 1862, KBA, 7-1-2.

${ }^{25}$ Letters for sisters, 1944-1998, KBA, 10-1-1. 
The $13^{\text {th }}$ fund stores questionnaires completed by the nuns. The questionnaires, as a part of empirical research conducted by Aušra Vasiliauskaitës licentiate and dissertation, contain information on American sisters and their activities during the soviet times. These funds are little researched and described.

In the $14^{\text {th }}$ fund, personal files of the sisters are collected. At present, there are several files such as the legacy of Sr. Leonija Birute Širvinkaitè (1924-2005). The file stores her memoirs and works. Sister Leonija was a very sociable person with many interests in history, literature, music, and theatre. She was actively involved in the reinstatement of the convent and the church, and the preservation of traditions of spirituality. Her writings portray the everyday life of the convent. ${ }^{26}$ This abundant legacy is valuable not only to the Kaunas Benedictine Convent, but also to Lithuania as a heritage of the cultural, historical, and monastic memory. This file contains more than 7,305 pages.

The $15^{\text {th }}$ fund (111 pages) includes the chronicle of the convent, written since the third decade of the $20^{\text {th }}$ century. The main authors were Sr. Leonija Birute Širvinkaite and Sr. Liucina Rozalija Rimšaite among others. ${ }^{27}$ In the $16^{\text {th }}$ fund, the history of Kaunas Benedictine Convent (112 pages) written by Sr. Leonija Birute Širvinkaite is stored. ${ }^{28}$

The $17^{\text {th }}$ fund consists of various documents of former and present property of the convent as, for example, the documents of the refrigerators, microwave, washing machines, etc.

The $18^{\text {th }}$ fund has a collection of the convent's publications issued in 1938 and 1944. Mostly, these are the newspapers by novices on the convent's realia. These publications are especially interesting as research material as they reflect the contemporary life of the convent. The reference name of the publication was "The Bells of St. Nicholas Mount" with various modification as "The Bells of St. Nicholas Hill". At present, this fund is made up of 80 pages.

The $19^{\text {th }}$ fund ( 1,160 pages) is dedicated to the convent's statutes, constitutions and customs. Written in the second half of the $2 \mathrm{O}^{\text {th }}$ century, it includes explanations, commentaries, declarations, and constitutions of St. Benedict's Rule

${ }^{26}$ For further reference on Sr. Leonija Birutė Širvinskaitė see: A. Vasiliauskaitè, Sister Leonija’s OSB (Birute Širvinskaite) manuscript legacy, "Soter: Journal of Religious Science" 48 (2013) 76, pp. 129-145.

${ }^{27}$ Sr. Liucina Rozalija Rimšaite, Convent's history, the $3^{\text {rd }}$ decade of the $20^{\text {th }}$ century, $K B A$, 15-1-2.

${ }^{28}$ Sr. Leonija (Birutė Širvinskaite), History of Kaunas Benedictines I, KBA, 16-1-1-1; Sr. Leonija (Birute Širvinskaitè), History of Kaunas Benedictines II, KBA, 16-1-1-2. 
and specific behaviour instructions for sisters working in further homes of the convent. Especially interesting are the Benedictine statutes and guidelines for Oblates and missionary sisters $(1970-1976) .{ }^{29}$ In addition, the fund contains the statutes of the convent dating from the $19^{\text {th }}$ to the beginning of the $20^{\text {th }}$ centuries. The statutes describe responsibilities of the sisters, the order of worship, the list of sins, and the ceremony of the consecration of the abbess.

The $20^{\text {th }}$ fund is dedicated to the documents necessary for the everyday affairs kept by the Reverend Mother. The $21^{\text {st }}$ fund (over 260 pages) includes: lists of sisters, ${ }^{30}$ convent's visitation documents of 1919, 1934, 1948, 1992-1999, ${ }^{31}$ as well as inventories of 1919,1920 , the second decade of the $20^{\text {th }}$ century, and $1934 .{ }^{32}$ Of particular importance are the documents of appointment of Reverend Mothers (1924-1943) ${ }^{33}$ and the inventory of the Dominican Monastery of Samogitian Calvary. ${ }^{34}$

The convent's book, started in the $18^{\text {th }}$ century, is stored in the $22^{\text {nd }}$ fund (over 384 pages). The book contains information about Benedictine dowries and convent's bills. ${ }^{35}$ On the basis of this information, Sr. Małgorzata Borkowska wrote an article about the economic situation of the Kaunas Benedictine Convent. ${ }^{36}$ The fund also includes acts of sisters' vows (1865-1997). ${ }^{37}$ The earliest acts of the vows $\left(17^{\text {th }}\right.$ c. - first half of the $19^{\text {th }}$ c.) were confiscated during the Soviet Period

${ }^{29}$ The St. Benedict's statutes and guidelines for Oblates and missionary sisters. 1970-1976; Pax. St. Benedict's statutes and guidelines for eremites and devoted missionaries - Benedictines, 1971, KBA, 19-1-5, 19-1-9, 19-1-12 (typescript).

${ }^{30}$ List of Benedictine nuns; News about sisters, 1934, KBA, 21-1-1; Registration of statutes of congregation; memories about the saving of the Jews. 1990-2002, KBA, 21-1-10.

${ }^{31}$ Visitations of Kaunas Benedictine Convent in 1948, 1934, 1919, etc. KBA, 21-1-2; S. Russel's visitation of the convent and other documents, 1992-1999, KBA, 21-1-3.

${ }^{32}$ Inventory of Kaunas Benedictine Convent, 1919 12, KBA, 21-1-5; Inventory of Kaunas Benedictine Convent, 192003 15, KBA, 21-1-6; Inventory of Kaunas Benedictine Convent, $2^{\text {nd }}$ decade of the $20^{\text {th }}$ century., KBA, 21-1-7; Inventory of Kaunas Benedictine Convent, 1934, KBA, 21-1-8.

33 Appointment of Reverend Mothers, 1924-1943, KBA, 21-1-4.

${ }^{34}$ The inventory of the Dominican monastery of Samogitian Calvary, 1856, KBA, 21-1-9.

${ }^{35}$ Convent's balance book, $18^{\text {th }}$ c. - beginning of $20^{\text {th }}$ c., $K B A, 22-1$.

${ }^{36}$ M. Borkowska OSB, Rachunki benedyktynek kowieńskich, in ks. St. Rospond CM (red.), Nasza Przeszłość. Studia z dziejów Kościoła i kultury katolickiej w Polsce, t. 106, Kraków 2006, pp. 261-278.

${ }^{37}$ Acts of nun vows, 1865-1948, KBA, 22-3; Acts of nun vows and related documentation, 1936-1997, KBA, 22-4. 
and are currently kept at the Manuscript Department of the Wroblewski Library of the Lithuanian Academy of Sciences. Finally, the fund stores the protocol books of the first half of the $20^{\text {th }}$ century.

The $23^{\text {rd }}$ fund contains various periodicals, books, extracts, etc., which mention the Kaunas Benedictine Convent. Publications also include articles by sisters on the spiritual life of the Benedictines in the convent, statistical data about sisters, history and facts related to convent and the church. Sr. Leonija Birute Širvinskaitës articles in "Krivulë" magazine can stand as an example of such publications.

The $24^{\text {th }}$ fund (over 4,518 pages) holds the documents of Benedictine sisters: Rozalija Rimkutè, Pranè Norvilaité, Laima Slizinaite, Vida Urbonaite, Angele Klètkutė, Birute Šlekytė, Eglè Diržiūtė, Bronè Makaravičiūtė, Agnè Čižaitė, Agota Misiūnaite, Salomėja Mikšytė, Justina Dobkevičiūtè, Valerija Strakšytė, and Bedford sisters' data. Some exceptional $19^{\text {th }}-20^{\text {th }}$ century files of the fund include: birth metrics, personal certificates, passports, retirement certificates, disability certificates, work books, ${ }^{38}$ death certificates, ${ }^{39}$ graduation certificates (first half of the $2 \mathrm{o}^{\text {th }} \mathrm{c}$.), student certificates, employment documents, ${ }^{40}$ note books (the end of the $2 \mathrm{O}^{\text {th }}$ - beginning of the $21^{\text {st }} \mathrm{c}$.)..$^{41}$

Income and expense documents of the third decade of the $20^{\text {th }}$ and the beginning of the $21^{\text {st }}$ centuries are stored in the $25^{\text {th }}$ fund. They include various estimates, bank statements, income and expense books (the most important books are those of 1941 and 1942-1945), ${ }^{42}$ checks, and cash advance orders. The $26^{\text {th }}$ fund keeps practical documents of the convent: electricity and heating bills, invoices, receipts and checks for utility services (water and premises, electricity, heating, and telephone communication), maintenance bills, lightning protection documents, documents related to heating, and Kaunas Energy documents.

${ }^{38}$ Birth metrics, personal certificates, passports, retirement certificates, disability certificates, work books, etc., $19^{\text {th }}-20^{\text {th }}$ c., KBA, 24-4-2.

${ }^{39}$ Death certificates, $K B A, 24-4-3$.

${ }^{40}$ Graduation certificates (first half of the $20^{\text {th }}$ c.), student certificates, employment documents, first half of the $20^{\text {th }} \mathrm{c}$., $K B A, 24-4-1$.

${ }^{41}$ Note book 1999, KBA, 24-2-1; Note book 2002, KBA, 24-2-2; Note book 2003, KBA, 24-2-3; Note book 2004, KBA, 24-2-4.

${ }^{42}$ Income and expense book, 1942-1945, KBA, 25-3-1; Income and expense book, 1941, $K B A, 25-3-2$. 
The $27^{\text {th }}$ fund consists of 266 books of the $17^{\text {th }}-20^{\text {th }}$ centuries: 3 books of the $17^{\text {th }}$ century, ${ }^{43} 5$ books of the $18^{\text {th }}$ century, ${ }^{44} 19$ books of the $19^{\text {th }}$ century, and the rest of them - written in the $2 \mathrm{O}^{\text {th }}$ century. This is what remained from the old library of the convent destroyed after the closure of the convent in 1948. Although theKaunas Benedictine Convent was restored, it did not recover the expropriated archives or the library.

${ }^{43}$ OFFICIA Propria SS. Patronorum SACRI ORDINIS DIVI BENEDICTI EX RECENTI BREVIARIO BENEDICTINO DESUMPTA ET Iuxta Rubricas Romani Breviarij usumq; Provinciae Polonae cum NONNULLIS CEREMONIIS in Sacro Ordine BENEDICTINO sieri solitis In gratiam sanctimonialium ejusdem Ordinis Utentium Romano Breviario PERMISSU SUPERIORUM Typis mandata Anno à Partu Virginis M. DC. LXXXI [1681]. KBA, 27-7-17.

O ZYWOCIE Y CUDACH S. BENEDYKTA OPATA, Wielu zakonow w Kośćiele Zachodnym sławnego PATRIARCHY TRAKTAT. Przytym Swiętey SCHOLASTYKI KSIĘNI, Swiętego MAURA OPATA, Swiętego PLACYDA OPATA Y M. Zywoty y cudá, od starodawnych Pisarzow po Łacinie pisane: á teraz ná Polski ięzyk, Przez W. X. STANISŁAWA SZCZYGIELSKIEGO, Opatá Trockiego, Zakonu S. Benedyktá przełożone, y do druku, w Wilnie, w Typografiey Soc: Iesu Roku Pańskiego 1683 podane. KBA, 27-8-17 ir 27-9-17 (two at the same books).

${ }^{44}$ Swięta przez pustynia zakonna droga do konsekracyi Panieństwa wiekuistego Oblubieńcowo Niebieskiemu zaślubionego. Abo rozmyslania na dźiesięć dni przed Konsekracya Panien Zakonnych z samego prawie Pontifikału prezez W. X. Marcina Bogumiła Grymosza S. J. T. sporzadzone roku od Panieństwa w Maryi Macierzyństwem Boskim uświęconego 1690. Teraz w Drukarni J. K. M. Akademickièy Soc. Jesu Roku 1756. KBA, 27-1-18.

Cwiczenia duchowne swiętego oyca Ignacego na osm dni rozłozone. Przez W. X. Ludwika Bourdaloue Soc. Jesu, francuskim językiem wydane. A przez X. Jerzego Devina tegoż Zakonu Kapłana na Oyczysty Język przełozone. Niegdyś w Kaliszu teraz w Wilnie. W Drukarni J. K. M. i Rzeczpltey Akad: Societatis Jesu. Roku Pańskiego 1773. KBA, 27-3-18.

OFFICIA PROPRIA PATRONORUM ORDINIS Nec non Et aliorum Regni Poloniae, ac Mag: Ducat: Litvaniae SANCTORUM AC BEATORUM Quae juxta Decreta Sac: Rit: Congregat: recitari quotannis debent à Monachis \& Monialibus Antiqui \& Celeberrimi Ordinis Benedictini, Pro usu commodiori Praesertim Sanctimonialium ejusdem Ordinis per Regnum Poloniae \& Magn: Ducat: Litvan: Studiosiori Compendio cum adjunctis Novissimis COLLECTA, à P. LEONARDO GRABKOWSKI Congregat: Bened: Polonae Archi-Caenobii Calvomontani San: Crucis Proses: p. t. in Ascaeterio Vilnen: VV. Monialium ad Aedes S. Catharinae V. M. Theologo Paenitentiario. Authoritate \& Permissu Illmi Loci Ordinarii. Anno Domini MDCCLIX [1759]. KBA, 27-6-18 ir 27-12-18.

Posel boskiey łaskawos[ci] albo wiełkich łask duchownyc[h] przedziwniey pannie y zakonnicy reguły Benedykta swiętego Gertrudzie s. bogomyslnoscią wielce sławney obwieszczenia wszelkiego stanu ludziom, do gorętszey się, w miłosci bozey zaprawy, bardzo pozyteczne. Piącią części tey xiążki opisane dawniey złacinskiego na polski język przetłumaczone a teraz powtornie dla pozytku zbawiennego za pozwoleniem starszych przedrukowane w Wilnie w drukarni J K Mci y Rzeczyposp. XX. Scholarum Piarum. Roku Pańskiego 1763. KBA, 2713-18. 
The documents are also complemented by the $28^{\text {th }}$ fund of the periodicals of the $2 \mathrm{O}^{\text {th }}$ century: magazines as "Mokslas ir gyvenimas", "Mūsų Vilnius", "Naujoji Sodyba", "Moteris", “Moteris ir pasaulis”, “Milujcie sie!”, “Židinys", “Naujoji Romuva", "Iliustruota Lietuva", "Krivulè, etc., individual publications and newspapers as "Pranciškonų pasaulis", "Lietuvos aidas", "Tiesos kelias", etc., calendars, extracts from various newspapers and magazines as "Sargyba", "Sąjūdžio Žinios", etc. The $29^{\text {th }}$ fund preserves the belongings of the deceased sisters with a historical value: for example, leather document tray, audio recording (last words), rosary and ring, funeral photo album and other things of Sr. Angelè Misiūnaite who worked for and took care of the Blessed Archbishop of Teofilius Matulionis until his death.

\section{The Value of the Archive of Kaunas Benedictine Sisters (Instead of Conclusions)}

The discussed archive of Kaunas Benedictine sisters includes documents from the $15^{\text {th }}$ to the $21^{\text {st }}$ centuries and authentic documents related to the convent's foundation. As the analysis has revealed, the largest part of the documents is related to the economic life of the convent. Information about the sisters' vow acts or personal files can be traced back to the $19^{\text {th }}$ century. A large part of the convent's archive was confiscated in 1948 when the soviet government closed the convent and the church. Nevertheless, the sisters managed to save most of the documents of the first half of the $20^{\text {th }}$ century, which are especially valuable for the studies of nuns' life in 1918-1945.

During the soviet times, Benedictines were working in secret and due to security reasons, did not keep the written records of their lives. That is why there is a shortage of documentation for this period. The lack of research of Benedictine activities in the soviet time is partly compensated by sisters' memoirs, especially the material collected by Sr. Leonija Birute Širvinskaite (e.g., obituaries, biographies and convent chronicles). Of course, the notes kept by other sisters have their own value, especially in the field of spiritual theology.

The documents stored in the archive provide data not only about Kaunas Benedictines, but also about other Lithuanian monasteries: Kražiai Benedictine Convent, Dominicans of Samogitian Calvary, Kaunas Jesuits and others.

The material also makes it possible to get a better understanding of the life of the people related to the convent, for example, the family of the convent's 
founders, Skorulskiai. This archive is important for the investigation of the history of Kaunas city and region as well as monastic heritage of the whole Lithuania.

The formation of the archives of the Benedictine sisters of Kaunas is not yet complete; it is continuously being updated with the documents of the deceased sisters; at present, the $20^{\text {th }}$ century documents and photographs are being registered. It can be said that only the documents of the $15^{\text {th }}-19^{\text {th }}$ centuries are fully registered and ordered. However, they may also be supplemented. For example, recently the Curia of Kaunas Archdiocese transferred a box with $19^{\text {th }}$ century economic documents, mostly contracts with the persons who lived in the jurisdiction of Benedictines. There may be more similar gifts in the future. Also, the Kaunas Benedictines have set a goal to accumulate copies of documents related to the history of the convent stored in Lithuanian and foreign archives in order to better understand the life of the Kaunas Benedictine Convent throughout the centuries of its existence.

\section{Bibliography}

Biblioteka Czartoryskich, BCz. 1775, 1. 963.

Borkowska M., Rachunki benedyktynek kowieńskich, in: St. Rospond CM (ed.), Nasza Przeszłość. Studia z dziejów Kościoła i kultury katolickiej w Polsce, t. 106, Kraków 2006, pp. 261-278.

Jankevičienè A., Dar apie šv. Mikalojaus bažnyčiq, "Kauno tiesa" 88 (1990), p. 5.

Kamuntavičienè V., Kauno benediktiniu vienuolyno tyrimai, t. 1. Kauno benediktiniu vienuolyno istorija XVII-XX a. pradžioje, Kaunas 2016, VDU, Versus Aureus.

Kamuntavičienè V., Vasiliauskaitė A. (Sr. Gabrielè OSB), Vasiliauskienè A., Žemaitis K., Kauno benediktiniu archyvo XV-XX a. pradžios dokumentu katalogas, "Kauno istorijos metraštis" 15 (2015), pp. 287-295.

Kauno arkivyskupijos kurijos archyvas (KAKA), b. 14, 1. 230.

Kauno benediktiniu archyvas (KBA) KBA, f. 7, f. 10, f. 15, f. 16, f. 19, f. 21, f. 22, f. 24 , f. 25, f. 27.

Laukaitytė R., Lietuvos vienuolijos. XX a. istorijos bruožai, Vilnius 1997, Lietuvos istorijos institutas, pp. 136-139.

Lietuvos centrinis valstybes archyvas (LCVA), f. R-181.

Lietuvos mokslu akademijos Vrubevskiu bibliotekos Rankraščiu skyrius (MAB), f. 38-3.

Lietuvos nacionalinis muziejus (LNM), f. R 11660-5.

Lietuvos valstybès istorijos archyvas (LVIA), f. 696-2-967.

Vasiliauskaitė A., Sister Leonija's OSB (Birute Širvinskaite) manuscript legacy, "Soter: 
Journal of Religious Science" 48 (2013) 76, pp. 129-145.

Vasiliauskienè A., Kauno benediktiniu vienuolyno tyrimai, t. 2. Kauno benediktiniu vienuolyno menine savastis, Kaunas 2016, VDU, Versus Aureus. 